\section{INCORPORATION OF ACALYPHA INDICA EXTRACT IN POLYVINYL ALCOHOL HYDROGELS: PHYSICO-CHEMICAL, ANTIBACTERIAL AND CELL COMPATIBILITY ANALYSES}

Mohamad Amin Jumata, Nor Syahiran Zahidina, Mohd Amirul Aizat Zainia, Nurul Afiqah Fadzila, Hadi Nurb, Syafiqah Saidina,c*

aSchool of Biomedical Engineering and Health Sciences, Faculty of Engineering, Universiti Teknologi Malaysia, UTM Johor Bahru, Johor, Malaysia

bCentre of Sustainable Nanomaterials, Ibnu Sina Institute for Scientific and Industrial Studies, Universiti Teknologi Malaysia, UTM Johor Bahru, Johor, Malaysia

cIJN-UTM Cardiovascular Engineering Centre, Institute of Human Centred Engineering, Universiti Teknologi Malaysia, UTM Johor Bahru, Johor, Malaysia
Article history

Received

15 March 2020

Received in revised form

15 December 2020

Accepted

4 January 2021

Published online

23 February 2021

*Corresponding author syafiqahs@utm.my
Graphical abstract
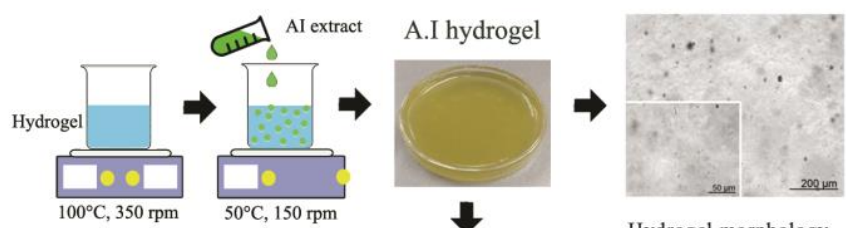

Hydrogel morphology

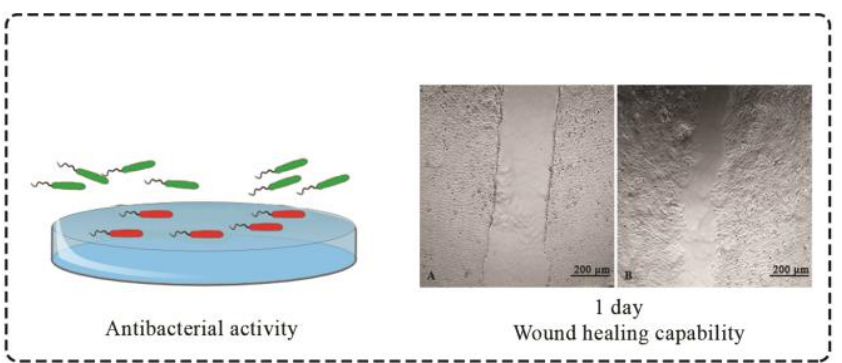

\begin{abstract}
Acalypha indica (A. indica) possesses antibacterial properties and has capability to accelerate wound healing due to its active therapeutic compounds of flavonoid and alkaloid. The incorporation of $A$. indica extracts in polymer hydrogels is useful for wound treatment, despite the advancement in synthetic medicines and drugs. In this study, polyvinyl alcohol (PVA) hydrogels with different concentrations of $A$. indica extract (0.5, 1.0, 1.5 and $2.0 \mathrm{mg}$ ) were fabricated. The ATR-FTIR spectra testified the presence of $A$. indica in the hydrogels. More enormous spotted agglomerations were visualized on the higher concentrations of $A$. indica hydrogels. The A. indica hydrogels became less moisture, more hydrophobic and has low water uptake ability compared to the control hydrogel (without A. indica). The antibacterial activities of the hydrogels against Escherichia coli and Staphylococcus aureus were acted in a dose-dependent manner where higher inhibition zones and higher bacterial retardations were recorded on the hydrogels with higher concentrations of $A$. indica. The incorporation of $A$. indica $(1.0-1.5 \mathrm{mg} / \mathrm{mL})$ has also induced cell viability, cell migration, and proliferation of the human skin fibroblasts. Therefore, optimization of the A. indica hydrogels is crucial in accommodating the bi-functional properties of antibacterial and biocompatibility for wound treatment.
\end{abstract}

Keywords: Acalypha indica, polymer hydrogel, wound healing antibacterial, biocompatible 


\begin{abstract}
Abstrak
Acalypha indica (A. indica) mempunyai sifat antibakteria dan mampu mempercepat penyembuhan luka kerana mempunyai sebatian terapi yang aktif iaitu flavonoid dan alkaloid. Penyatuan ekstrak $A$. indica di dalam hidrogel polimer adalah berguna untuk rawatan luka, walaupun terdapat kemajuan dalam ubat sintetik dan dadah. Dalam kajian ini, hidrogel alkohol polivinil (PVA) dengan kepekatan ekstrak $A$. indica $(0.5,1.0,1.5$ dan $2.0 \mathrm{mg})$ yang berbeza telah difabrikasi. Spektra ATR-FTIR membuktikan kehadiran A. indica di dalam hidrogel. Gumpalan yang lebih besar dapat dilihat pada hidrogel $A$. indica yang mempunyai kepekatan lebih tinggi. Hidrogel $A$. indica menjadi kurang lembap, lebih hidrofobik dan mempunyai keupayaan pengambilan air yang rendah berbanding hidrogel kawalan (tanpa $A$. indica). Tindakan aktiviti antibakteria oleh hidrogel terhadap Escherichia coli dan Staphylococcus aureus adalah bergantung kepada dos di mana zon perencatan dan pengurangan bakteria yang banyak telah direkodkan pada hidrogel dengan kepekatan $A$. indica yang lebih tinggi. Penggabungan A. indica (1.0 - 1.5 $\mathrm{mg} / \mathrm{mL}$ ) juga mendorong kebolehhidupan, migrasi dan pertumbuhan sel fibroblas kulit manusia. Oleh itu, pengoptimuman hidrogel $A$. indica adalah penting dalam menampung ciri-ciri bi-fungsi antibakteria dan bioserasi untuk rawatan luka.

Kata kunci: Acalypha indica, hidrogel polimer, rawatan luka, antibakteria, bioserasi

(C) 2021 Penerbit UTM Press. All rights reserved
\end{abstract}

\subsection{INTRODUCTION}

Wound healing and wound management are among challenging clinical problems despite the advancements in medical technology and research [1]. Wound can be described as a break or discontinuation in the skin or mucous membrane [2]. Wound healing occurs typically in a very efficient and orderly manner, which can be described in four overlapping phases; hemostasis, inflammation, proliferation, and remodeling [3]. There are many factors involved in a wound healing process. Some factors help and facilitate wound healing, while the others affect and delay wound healing. One of the main factors that will delay wound healing process is, an infection by microorganisms. Once the skin is injured, microorganisms that inhabit the skin surfaces will obtain access to the underlying tissues [4]. The injured skin and open wound are also exposed to various microorganisms from the surrounding environment, subjecting the wound to infection [5].

Delayed wound healing has a significant impact on the health and patient's life quality, causing pain, loss of function and mobility, distress, anxiety and depression, embarrassment, financial burden and prolonging hospital admission. In the worst case, it could lead to a chronic morbidity. For example, in the United States of America, it is reported that chronic wounds have affected 6.5 million patients with more than US\$25 billion each year, spent on treating wound and wound-related complications [6]. The costly nature of wound management is further evident in the United Kingdom, where the National Health Service was reported to spend an estimated amount of US $\$ 3.4$ to 4.6 billion per year (in 2005) for caring the patients with chronic wounds, which represented around $3 \%$ of total estimated expenditure on the society's health for the same year [6].

Along with the advancements in medical research and technology, wound dressing techniques and devices have evolved from a traditional dressing towards a modern wound dressing technique. Nowadays, various wound dressing techniques and devices are found available in the medical and pharmaceutical wound care markets, globally [7]. The main goal of wound management and wound dressing is to keep the wound in an optimum condition which can facilitate wound healing process and prevent delayed wound healing from occurring. It has now been proven that, a warm moist wound environment and a wound condition that is protected from an infection can achieve more rapid and successful healing [7-9].

Wound dressing techniques have been developed over past decades from the application of traditional crude herbal plant to a modern tissue engineered scaffold [7]. Many traditional herbal plants exhibit antibacterial activities, which have potential to be combined with modern dressing 
techniques to promote wound healing [8]. Acalypha indica $(A$. indica) is one of the traditional herbal plants that has been acknowledged as a useful source for various therapeutic treatments especially for wound healing due to its antibacterial properties and its ability to accelerate wound closure $[9,10]$. Alkaloid and flavonoid are two most active phytochemical compounds in A. indica which are responsible for its antibacterial properties and wound healing ability $[11,12]$. Specifically, the wound healing activity of $A$. indica is assisted by antioxidant flavonoids of hesperetin, galangin, kaempferol and quercetin [13]. This herbal plant has a good potential to be used in combination with a modern wound dressing technique such as hydrogel dressing. For wound healing application, a hydrogel dressing is commonly made of synthetic hydrophilic polymer which can be applied, either as an amorphous gel or as an elastic and solid sheet on wounds [7]. In this study, A. indica extractions were incorporated into polyvinyl alcohol (PVA) hydrogels at different concentrations. The $A$. indica hydrogels were characterized with an attenuated total reflectanceFourier transform infrared spectroscopy (ATR-FTIR), inverted microscopy and contact angle instrument. Its water uptake properties, antibacterial activity and cell compatibility were then evaluated to assess the capability of $A$. indica hydrogels in addressing wound healing application.

\subsection{METHODOLOGY}

\section{Acalypha indica Extraction}

The chemical reagents of 2,2-diphenyl-1picrylhydrazyl (DPPH) and PVA were purchased from Sigma Aldrich, USA. The tablets of phosphate buffer saline (PBS) were purchased from Biobasic, Canada, while propylene glycol (PG) and carbopol were purchased from a local supplier. Acalypha indica was cultivated in a plot with a GPS location of $1^{\circ} 32^{\prime} 38.5^{\prime \prime} \mathrm{N}, 103^{\circ} 38^{\prime} 00.8^{\prime \prime} \mathrm{E}$ in the School of Biomedical Engineering and Health Sciences, Faculty of Engineering, Universiti Teknologi Malaysia. The plant species were verified at the herbarium of the Institute of Bioscience, Universiti Putra Malaysia, with a voucher number of SK 3146/17. Five months after the cultivation, the whole plant part was harvested and washed with tap water to remove dirt and foreign object. The plant was left dried at room temperature. It was then dried properly in a drying oven (Universal Oven UF1 10, Memmert, Germany) at $60^{\circ} \mathrm{C}$ for $12 \mathrm{~h}$ to remove moisture content.

The brittle and crispy structure of the dried plant causes the plant to be easily pulverized and processed. The dried plant was chopped into pieces, pulverized using a blender (Blender HGB-550, Waring, USA) and loaded into a sieve shaker (M200 Miniature Laboratory Sieve Shaker, Endecotts, UK) to obtain less than $1 \mathrm{~mm}$ size of powders. The powders of $A$. indica were placed inside a cellulose thimble and extracted using a soxhlet extractor (Behr, Labor-Technik, Germany). The extraction process was performed for 1 day using ethanol as the extraction solvent. The extract solution was then dried in a drying oven (Universal Oven UF110, Memmert, Germany) at $60^{\circ} \mathrm{C}$ to obtain a crude extract and finally stored in a freezer at $-4^{\circ} \mathrm{C}$. Flavanoid and alkaloid are expected to be extracted from the $A$. indica plant.

\section{Fabrication of $A$. indica Hydrogels}

A mixture of $15 \mathrm{~mL}$ of distilled water and $7.5 \mathrm{~mL}$ of PG were heated, up to $70^{\circ} \mathrm{C}$. PG is important for the maintenance of jelly-like hydrogel structure at low temperature. The mixture was then incorporated with $2.5 \mathrm{mg}$ PVA and further stirred continuously at $100^{\circ} \mathrm{C}$. Once the temperature reached $100^{\circ} \mathrm{C}, 25 \mathrm{mg}$ carbopol 2020 was added to the PVA hydrogel matrix as a thickening agent, with a continuous stirring to prevent the carbopol from clumping. The hydrogel matrix was then let cooled and proceed with the addition of four different concentrations 10.5 , 1.0, 1.5 and $2.0 \mathrm{mg} / \mathrm{mL}$ ) of ethanolic extract of $A$. indica at $50^{\circ} \mathrm{C}$. Prior to the addition, the $A$. indica extracts were diluted in 1:1 ratio of ethanol and distilled water. The incorporation of $A$. indica extracts was performed in the hydrogel liquid state to retain its therapeutic values and to prevent the denaturation of phytochemical compounds. The $A$. indica hydrogels were labelled as $0.5 \mathrm{Al}, 1.0 \mathrm{Al}, 1.5 \mathrm{Al}$ and $2.0 \mathrm{Al}$, respectively, while the hydrogel without $A$. indica was set as the control. Finally, the hydrogels were casted in a petri dish and frozen for $24 \mathrm{~h}$ for further analysis.

\section{Characterization of Hydrogels}

The chemical functionalities of the hydrogels were identified by ATR-FTIR (Nicoler iD5, Thermo Scientific, USA). The analysis was conducted using a zinc selenide (ZnSe) crystal at $4 \mathrm{~cm}^{-1}$ resolution. The ATRFTIR spectra were obtained within a frequency range of $500-4000 \mathrm{~cm}^{-1}$ at 32 average scans. The surface morphology of the hydrogels was then visualized under an inverted microscope (Carl Zeiss Axio Vert Al, USA) at $5 \times$ and $20 \times$ magnifications in a bright field mode.

While, the video contact angle system (VCA Optima, AST Product, Inc.,USA) was used to determine the wettability of the hydrogels. An amount of $2 \mu \mathrm{L}$ of distilled water was dropped on the hydrogel surfaces. The contact angle data were then recorded at a time point of $2 \mathrm{sec}$ following the dropping. An average angle of three different drops at three different spots were collected to examine the homogeneity of wettability measurements. 


\section{Water Uptake Analysis}

The hydrogels were punched into a cylindrical shape of $12 \mathrm{~mm}$ diameter and $2 \mathrm{~mm}$ thickness. The punched hydrogels were immersed in $10 \mathrm{~mL}$ distilled water at room temperature to assess its water uptake ability. The water uptake of hydrogels was then measured at time points of $0,0.5,1,2,3,6$ and $12 \mathrm{~h}$ by recording the increment of hydrogel diameter. The data of increment were fitted into Equation 1 to calculate the water uptake percentage.

Water uptake $(\%)=\left(D_{f}-D_{i}\right) / D_{i} \times 100$

where $D_{f}$ is the final diameter of the hydrogels at specific time point and $D_{i}$ is the initial diameter of the hydrogels prior to the water uptake test.

\section{In-vitro Antibacterial Analysis}

The antibacterial properties of the $A$. indica hydrogels were tested against two different bacterial strains; Escherichia coli (ATCC 11229) and Staphylococcus aureus (ATCC 6538), which represented Gram-negative and Gram-positive bacteria, respectively. Prior to the experiment, the bacteria were grown on nutrient agars and incubated for $24 \mathrm{~h}$ at $37^{\circ} \mathrm{C}$. Using a sterile inoculation loop, a single colony of each bacteria was transferred into $100 \mathrm{~mL}$ of Luria-Bertani (LB) broth. The cultures were incubated for $16 \mathrm{~h}$ in a shaking incubator, set at $200 \mathrm{rpm}$. The colony forming unit (CFU) of $1 \times 10^{8} \mathrm{E}$. coli and S. aureus bacteria were determined using a spectrophotometer at an absorbance wavelength of $600 \mathrm{~nm}$ for further use.

The antibacterial activities were investigated through quantitative analyses of disc diffusion and bacterial count in triplicate. For the disc diffusion analysis, the punched hydrogels were placed firmly on LB agar plates, which have been smeared with $100 \mu \mathrm{L}$ of inoculum containing approximately $1 \times 10^{8}$ $\mathrm{cfu} / \mathrm{mL}$ of tested bacteria. The plates were then incubated at $37^{\circ} \mathrm{C}$ for $24 \mathrm{~h}$. After $24 \mathrm{~h}$, the inhibition zones (length between sample edge and inhibition boundary) were measured using a mobile application ImageMeter - Photo Measure v2.18.0 (Dirk Farin, Germany).

While, the bacteria count analysis was investigated by immersing the punched hydrogels in $5 \mathrm{~mL}$ of bacterial suspension. The suspensions were then incubated for $3 \mathrm{~h}$ in a shaking incubator at 200 rpm. Subsequently, the suspensions were diluted to eight dilution series. A drop plate method was used for bacterial enumeration. An amount of $10 \mu \mathrm{L}$ of each dilution series was dropped on nutrient agars which then, were incubated at $37^{\circ} \mathrm{C}$ for $24 \mathrm{~h}$. The bacterial colonies that are formed on the agar were counted manually to determine the CFU. Finally, the reduction percentages (bactericidal) were calculated based on Equation 2 where $\mathrm{CFU}_{c}$ is the bacterial CFU on the control hydrogel and CFU $U_{A i}$ is the bacterial CFU on the A. indica hydrogel.

$$
\text { Bactericidal }(\%)=\left(\mathrm{CFU}_{C}-\mathrm{CFU}_{\mathrm{Ai}}\right) / \mathrm{CFU}_{\mathrm{C}} \times 100
$$

\section{In-vitro Cytocompatibility Analysis}

Human skin fibroblasts (HSF 1184, ECACC, UK) were cultured in a complete medium of mixture Gibcoß MEM Minimum Essential Medium and supplemented with $10 \%(\mathrm{v} / \mathrm{v})$ fetal bovine serum (FBS) and $1 \%(100$ $\mathrm{U} / 1 \mu \mathrm{g} / \mathrm{mL}$ ) penicillin/streptomycin in a ratio of 100:10:1. The cells were incubated in a humidified incubator at $37^{\circ} \mathrm{C}$ with $5 \% \mathrm{CO}_{2}$ until reached the confluency of $80 \%$. The cells were detached with Gibco $^{\text {TM }}$ TryplE Express Enzyme, counted using a haemacytometer, seeded in 24-well plates and further incubated in a humidified incubator at $37^{\circ} \mathrm{C}$ and $5 \% \mathrm{CO}_{2}$.

The in-vitro cytocompatibility analyses of $A$. indica hydrogels were conducted through cell cytotoxicity analysis and cell scratch assay. For the cell cytotoxicity analysis, the extraction media of the hydrogels were prepared by immersing the hydrogels into a complete supplemented medium. The extraction media were stored in a refrigerator for a week. The $100 \%$ confluent HSF cells were then treated with the $A$. indica extraction media for $24 \mathrm{~h}$ to assess the cell viability. After $24 \mathrm{~h}$, the extraction media were removed and $1 \mathrm{~mL}$ of $12 \mathrm{mM} 3-(4,5-$ Dimethylthiazol-2-yl)-2,5-diphenyltetrazoliumbromide (MTT) solution (Invitrogen, USA) were pipetted to each well. The well plates were then further incubated for $4 \mathrm{~h}$ at $37^{\circ} \mathrm{C}$ with $5 \% \mathrm{CO}_{2}$. A total of 1 $\mathrm{mL}$ of dimethylsulfoxide (DMSO) was added into each well to replace the MTT solution. The cell viability was finally measured using a microplate reader (Thermo Scientific, Multiskan FC 51119000, Taiwan) at $570 \mathrm{~nm}$. The results were expressed as relative growth rate (RGR) following Equation 3 using the measurement data of optical density (OD) where $O D_{A i}$ is the OD for cells treated with the $A$. indica hydrogels and $O D_{c}$ is the OD for cells treated with the control hydrogel.

$\operatorname{RGR}(\%)=O D_{A i} / O D_{c} \times 100$

The effects of $A$. indica hydrogels on HSF 1184 were then accessed through the cell scratch assay. A small linear scratch was created in the confluent monolayer culture by scraping the cells with sterilized $200 \mu \mathrm{L}$ pipette tip. The media in the 24-well plates were then replaced with corresponding extraction media. Each well was observed under a bright-field mode of inverted fluorescent microscope (Carl Zeiss Axio Vert Al, USA) at $5 \times$ magnification. The images of the cells were captured to measure the initial length of the scratched gap. The well plates were then incubated at $37^{\circ} \mathrm{C}$ with $5 \% \quad \mathrm{CO}_{2}$. After $24 \mathrm{~h}$ incubation, each plate was observed again to determine the gap length. The length was finally measured using Image J software (ImageJ 1.51k, NIH, USA). The results were expressed as percentages of the gap closure which can be calculated using Equation 4. 
Gap closure $(\%)=\left(\left(G_{i}-G_{f}\right) / G_{i}\right) \times 100$

where $G_{i}$ is the initial gap length and $G_{f}$ is the final gap length after $24 \mathrm{~h}$ incubation.

\subsection{RESULTS AND DISCUSSION}

\section{ATR-FTIR Analysis}

Figure 1 represents the ATR-FTIR spectra of control, A. indica extract, $0.5 \mathrm{Al}, 1.0 \mathrm{Al}, 1.5 \mathrm{Al}$ and $2.0 \mathrm{Al}$ hydrogels. The control which set to the hydrogel without the incorporation of $A$. indica, comprised of a high peak of hydroxyl group (O-H) at $3200-3500$ $\mathrm{cm}^{-1}$. The hydrogels were mostly constructed of water-based molecules that protected the hydrogels from dehydration and maintained the properties of water uptake and wettability. Alkane $(\mathrm{C}-\mathrm{H})$, carbonyl stretch $(C=O)$, aromatic stretch carbon ring $(C-C)$ and bend alkene $(=\mathrm{C}-\mathrm{H})$ peaks were also observed on the control spectrum at $2850-3000 \mathrm{~cm}^{-1}, 1640$ $1680 \mathrm{~cm}^{-1}, 1400-1500 \mathrm{~cm}^{-1}$ and $650-1000 \mathrm{~cm}^{-1}$, respectively, indicated the existence of hydrogel compound.
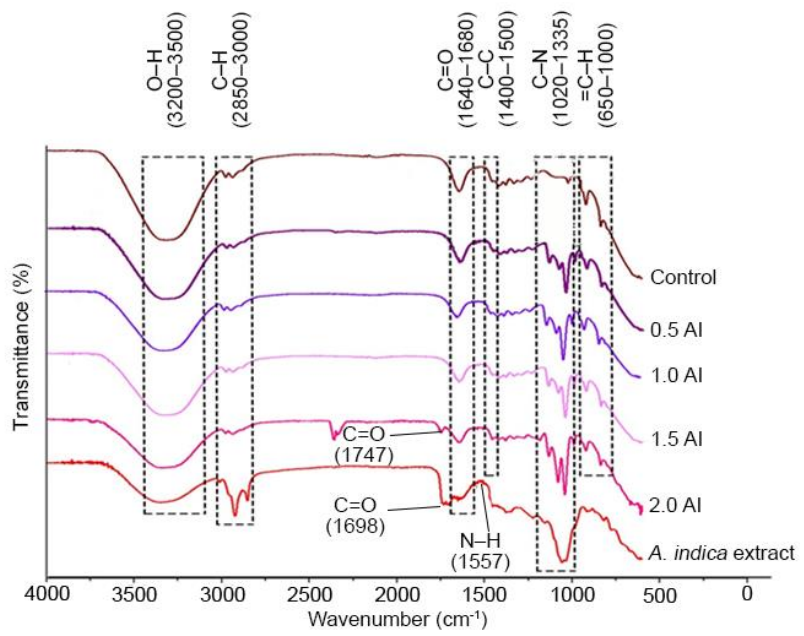

Figure 1 ATR-FTIR spectra of control, A. indica extract, $0.5 \mathrm{Al}$, $1.0 \mathrm{Al}, 1.5 \mathrm{Al}$ and $2.0 \mathrm{Al}$ hydrogels

The A. indica extract has the annotation of another small peak of carbonyl group $(\mathrm{C}=\mathrm{O})$ at $1698 \mathrm{~cm}^{-1}$, primary amine $(\mathrm{N}-\mathrm{H})$ bend at $1557 \mathrm{~cm}^{-1}$ and aromatic amine $(\mathrm{C}-\mathrm{N})$ at $1020-1335 \mathrm{~cm}^{-1}$. These observations justified that the extract was consisted of an amide linkage and active compounds of $A$. indica. The incorporation of $A$. indica extracts within the hydrogels cause the appearance of slightly similar peaks with the control hydrogel and the $A$. indica extract. The $\mathrm{C}=\mathrm{O}$ in the amide linkage contributed to the structure of plant protein where the amide linkage gave structural rigidity to the hydrogel in resisting hydrolysis [14, 15]. While the primary amine structure $(\mathrm{N}-\mathrm{H})$ was belong to the active compounds of $A$. indica which demonstrating the characteristic of alkaloid, flavanoid and terpenoid in the A. indica $[14,15]$.

\section{Morphological Analysis}

The surface morphologies of $A$. indica hydrogels were examined by an inverted microscopy in a bright field mode at $5 \times$ and $20 \times$ magnifications (Figure 2). As the concentration of $A$. indica increased, more agglomerations were observed in the hydrogels. The agglomeration compound was identified to be the clumping of non-dissolved $A$. indica extract. The A. indica was extracted through an ethanol extraction technique which has a different dissolvability with the main solvent of the hydrogels, distilled water. Repulsion of different dissolvability cause the extract compound to be clumpy and agglomerated.

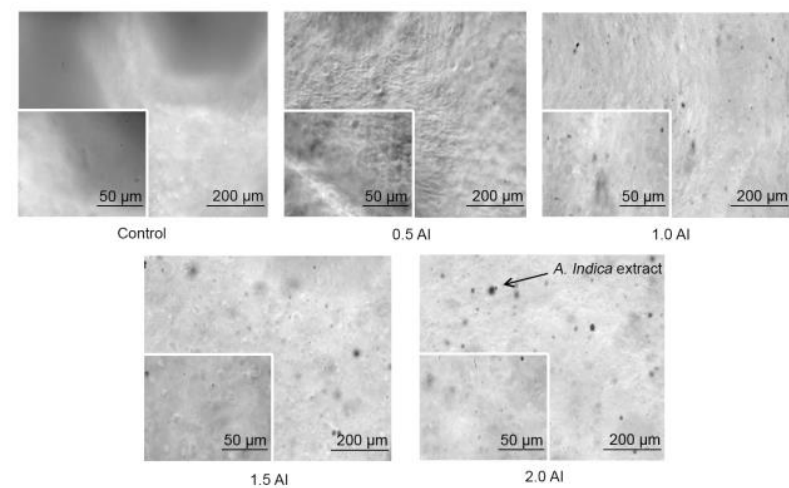

Figure 2 Surface morphologies of control, 0.5 Al, 1.0 Al, 1.5 Al and 2.0 Al hydrogels

\section{Water Contact Angle Analysis}

The wettability of the A. indica hydrogels was evaluated by the contact angle measurement. The contact angle measurements (Figure 3 ) show that as the concentration of $A$. indica increased, the contact angle values increased from $30.30^{\circ} \pm 1.47$ to $39.23^{\circ} \pm 2.14$, forwarding the hydrogels into less wettability.

These results are accordance to the ATR-FTIR and morphological analyses where a high amount of water content was recorded on the control hydrogel. Thus, it can be concluded that the extraction of $A$. indica was consisted of major non-polar components which tended to dissolve with non-polar structures of ethanol, led to less wettability properties of the A. indica extract $[16,17]$. 


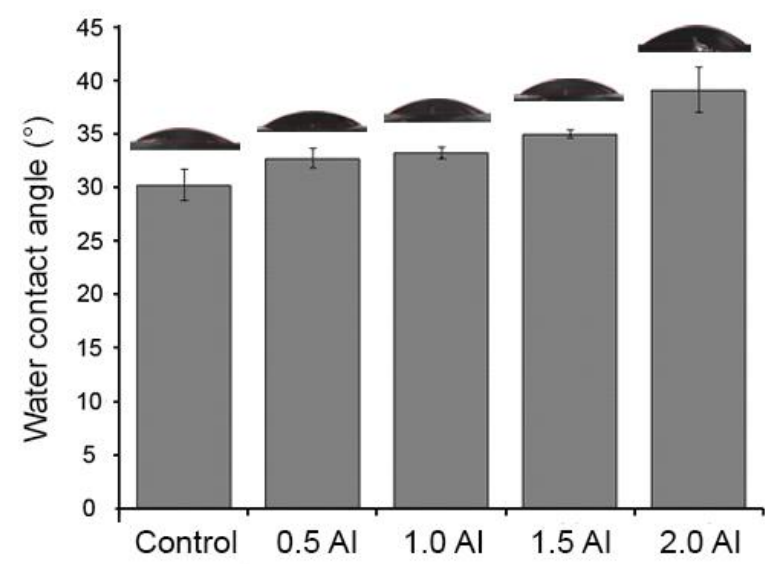

Figure 3 Contact angle measurements on control, $0.5 \mathrm{Al}, 1.0$ $\mathrm{Al}, 1.5 \mathrm{Al}$ and $2.0 \mathrm{Al}$ hydrogels

\section{Water Uptake Analysis}

The water uptake analysis was conducted to identify the water uptake properties of hydrogel by immersing the hydrogels in distilled water at several time points. Figure 4 shows the increment percentages of hydrogel length against the time point of water uptake.

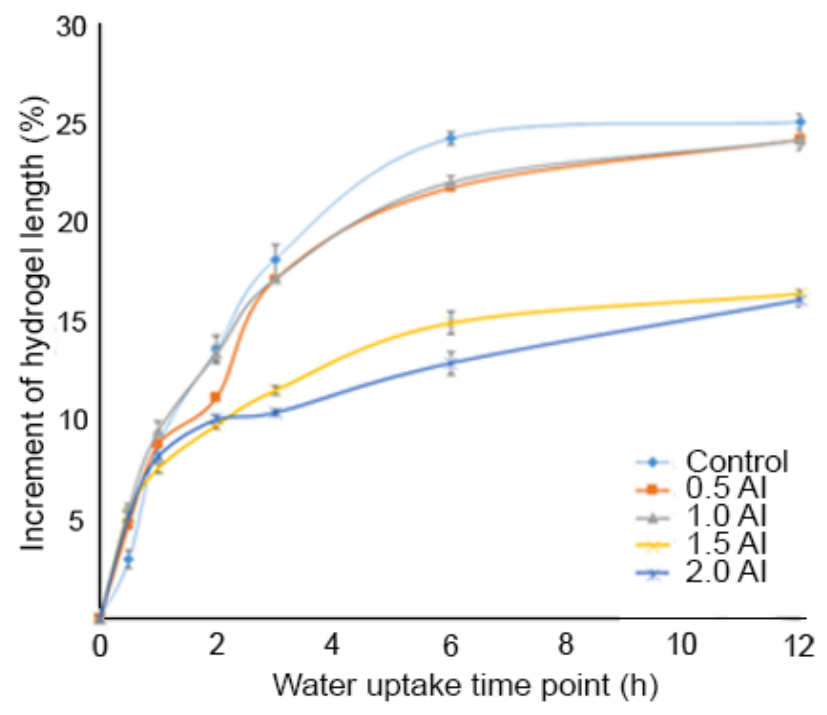

Figure 4 Percentages of length increment of control, $0.5 \mathrm{Al}$, 1.0 Al, 1.5 Al and 2.0 Al hydrogels

The hydrogels undergo rapid water uptake at the first stage (over-water uptake stage) from 0 to $1 \mathrm{~h}$ as the increment percentages have increased drastically, indicated by the steep slope gradient. The second and third stages were observed at the 1 until $6 \mathrm{~h}$ of water uptake time. The hydrogels undergo changes in water uptake properties by which the water uptake level varied [18]. The fourth stage of water uptake can be observed at the time points between 6 and $12 \mathrm{~h}$ where the increment percentages were increased slowly.

If the water uptake procedure continues, there will be a fixed increment percentage in the length of hydrogel which indicates no water uptake behavior. This procedure was not conducted in this study as the hydrogel structure was dissolved too rapidly in distilled water. It can be generalized that the increment percentages in the length of hydrogels were further decreased with time until a nearly plateau shape of graph was observed at the $12 \mathrm{~h}$ of time point. The results also justified that the highest water uptake was recorded on the control hydrogel, followed by the $0.5 \mathrm{Al}, 1.0 \mathrm{Al}, 1.5 \mathrm{Al}$ and $2.0 \mathrm{Al}$ hydrogels. This trend was observed due to the increase in hydrophobicity of the hydrogels when the concentration of $A$. indica extracts increased.

According to the previous studies, when the attraction between polymer molecules and solvent surround is stronger than the attraction of molecule within the polymer itself, the polymer will tend to induce its water uptake behavior [11]. This reflects the results in this study, where the incorporation of $A$. indica extract inside the hydrogels has increased the attraction between polymer molecules more than the attraction between polymer molecules and solvent surround, thus contributing to less hydrogel water uptake.

\section{Antibacterial Evaluation}

The antibacterial activities of the A. indica hydrogels against E. coli (Gram-negative) and S. aureus (Grampositive) were studied based on the presence of inhibitory zones around the hydrogels on the agar (Table 1). The disc diffusion test was used to determine whether there is a diffusion of antibacterial agents from the hydrogels onto the agar that can inhibit bacterial growth. As seen from the result, the inhibition zones increased with the increasing of $A$. indica concentration in the hydrogels for both types of bacterial species.

Table 1 Zone inhibition length of control, $0.5 \mathrm{Al}, 1.0 \mathrm{Al}, 1.5 \mathrm{Al}$, $2.0 \mathrm{Al}$ hydrogels

\begin{tabular}{lll}
\hline Hydrogel & $\begin{array}{l}\text { Average distance of inhibition zone } \\
(\mathbf{m m})\end{array}$ \\
\cline { 2 - 3 } & E. coli & S. aureus \\
\hline Control & $0.45 \pm 0.07$ & $0.73 \pm 0.09$ \\
$0.5 \mathrm{Al}$ & $0.50 \pm 0.08$ & $0.85 \pm 0.07$ \\
$1.0 \mathrm{Al}$ & $0.55 \pm 0.04$ & $1.11 \pm 0.05$ \\
$1.5 \mathrm{Al}$ & $1.41 \pm 0.05$ & $2.19 \pm 0.08$ \\
$2.0 \mathrm{Al}$ & $1.75 \pm 0.14$ & $2.43 \pm 0.03$ \\
\hline
\end{tabular}

The antibacterial activity of the A. indica hydrogels was further investigated by determining the reduction of viable bacteria through the bacterial count test. The results in Figure 5 shows the reduction percentages of $E$. coli and $S$. aureus 
viabilities for all $A$. indica hydrogels after $3 \mathrm{~h}$ of incubation.

Similar to the results of inhibition zones, the reduction percentages of bacterial viability was increased as the concentration of $A$. indica extraction increased. Interestingly, the $S$. aureus (Gram-positive) were more susceptible towards the antibacterial effect of $A$. indica hydrogels compared to the E. coli (Gram-negative).

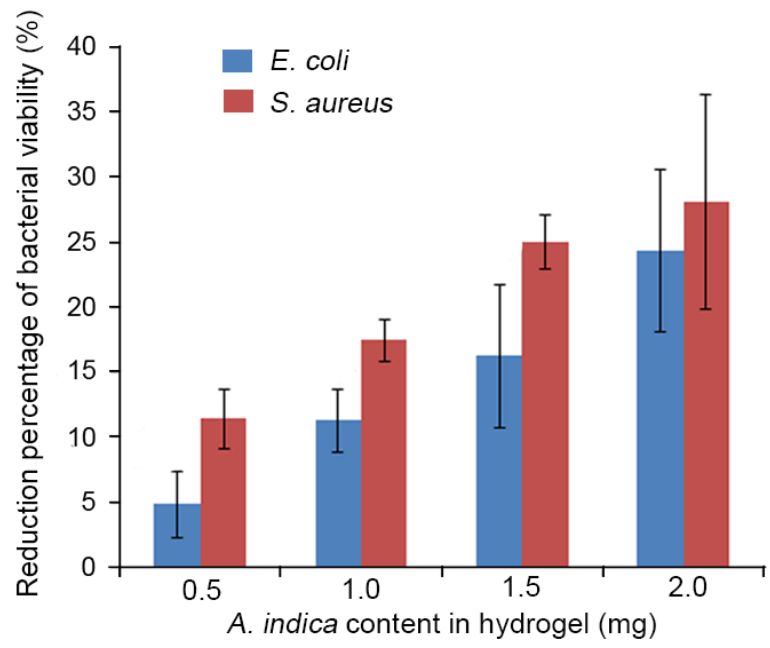

Figure 5 Reduction percentages of bacterial viability on 0.5 $\mathrm{Al}, 1.0 \mathrm{Al}, 1.5 \mathrm{Al}$ and $2.0 \mathrm{Al}$ hydrogels against $E$. coli and $\mathrm{S}$. aureus

Previous studies also found similar trends of susceptibility as the Gram-positive bacteria are only constructed of a peptidoglycan layer which is not an effective permeability barrier towards the antibacterial agent of $A$. indica $[19,20]$. While in the Gram-negative bacteria, a lipopolysaccharide layer, together with proteins and phospholipids constitute the major components of the outer surface of bacteria, thus contributing to bacterial resistivity [19, 20].

The antibacterial effect of the A. indica hydrogels is prominently conducive due to the presence of phytochemical substances in this plant such as phenols, tannins, alkaloids and saponins that able to disturb and destroy the bacterial cell wall in a different way $[12,21]$. The water and ethanolic extractions also showed better antibacterial properties against Gram-positive bacteria and they are as potent as other commercial antibiotics such as chloramphenicol, penicillin-G and ampicillin $[19,22]$.

\section{Cell Compatibility Analysis}

The conducted MTT assay (Figure 6 (a)) demonstrate, all hydrogels incorporated with different concentrations of $A$. indica extract exhibited minimal cytotoxic effects towards the HSF cells with over than $70 \%$ viability. Previous studies reported that the ethanolic extraction of $A$. indica was found to be moderately cytotoxic at higher concentrations [23, 24]. However, according to the classification criteria of cytotoxicity reaction, a value of cell viability, higher than $75 \%$ is considered safe for cell growth [25]. Therefore, the hydrogels with less than 1.5 $\mathrm{mg} / \mathrm{mL}$ ethanolic extract of $A$. indica can be considered cytocompatible.
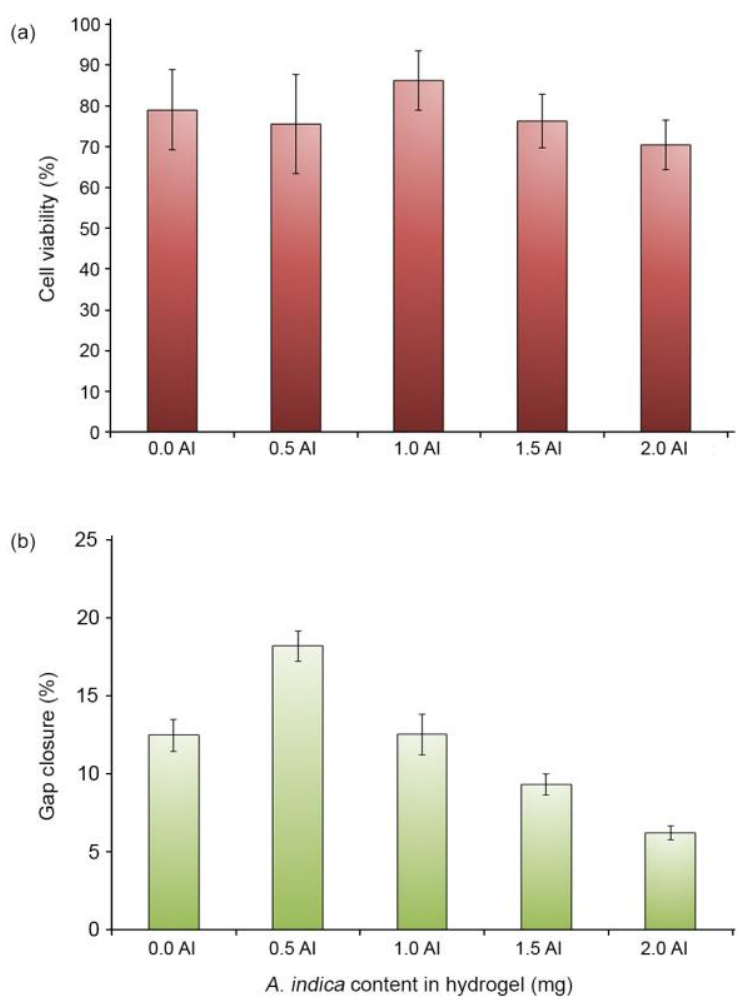

Figure 6 Percentages of (a) HSF cell viability and (b) gap closure on control, 0.5 Al, 1.0 Al, 1.5 Al and 2.0 Al hydrogels

The effect of different concentrations of $A$. indica hydrogels on cell migration and proliferation of HSF cells was assessed through the cell scratch test of a confluent monolayer cell culture. The cells with and without hydrogel treatment were allowed to migrate into the denuded area for $24 \mathrm{~h}$ at $37^{\circ} \mathrm{C}$ under the supplement of $5 \% \mathrm{CO}_{2}$. The gap closures were then determined and the results were represented in Figure 6 (b). The cells migration and proliferation increased after the incorporation of $A$. indica, which peaked at $(18.20 \pm 0.96) \%$ for the $0.5 \mathrm{mg} / \mathrm{mL}$ concentration. However, at higher concentration, the cells treated with the hydrogels were less mobile, as indicated by lower cells migration and proliferation after $24 \mathrm{~h}$ at the concentration of 1.0 $\mathrm{mg} / \mathrm{mL}$ and above.

A. indica plant contains phytochemical compounds such as flavonoids which are strong scavengers of reactive oxygen species [13]. Flavonoids will accelerate wound healing by modulating the concentration of reactive oxygen species [13]. These phytochemicals possess mitogenic properties that can enhance cell division, 
hence accelerating wound healing [22]. At higher concentration, $A$. indica has tendency to accommodate bi-functional properties by inhibiting bacteria and supporting cell growth. In this study, the incorporation of $1.5 \mathrm{mg} / \mathrm{mL} A$. indica extract into the PVA hydrogel is considered as the optimum value in supplementing antibacterial effect without causing harm to cells.

\subsection{CONCLUSION}

The incorporation of $A$. indica extract within the hydrogels is intended for wound care and treatment. In this study, the biocompatible A. indica hydrogels were found to have moisture, water uptake and antibacterial capabilities. Increasing the concentration of $A$. indica extract has induced the extract agglomeration and reduced the wettability and water uptake percentages. The A. indica hydrogels exhibited significant antibacterial activities against $E$. coli and $S$. aureus with greater retardation on the S. aureus. At the concentration higher than 1.5 $\mathrm{mg} / \mathrm{mL}$, the $A$. indica hydrogels have tendency to reduce cell viability, migration and proliferation. Therefore, optimizing the concentration of $A$. indica to be incorporated within hydrogels is crucial in accommodating the hydrogels with antibacterial effect without causing harm to cells for the application of wound care and treatment.

\section{Acknowledgement}

This study was supported by Research University Grant Tier 1 [Q.J130000.2545.18H40], given by Malaysian Ministry of Higher Education (MOHE).

\section{References}

[1] Ali, A. M., Mackeen, M. M., Ei-Sharkawy, S. H., Hamid, J. A. Ismail, N. H., Ahmad, F. B., and Lajis, N. H. 1996. Antiviral and Cytotoxic Activities of Some Plants Used in Malaysian Indigenous Medicine. Pertanika Journal of Tropical Agricultural Science. 19(2/3): 129-136. https://doi.org/10.1177/0743558411417864.

[2] Begam, T., Nagpal, A. K., and Singhal, R. 2003. A Comparative Study of Swelling Properties of Hydrogels Based on Poly (acrylamide- co -methyl methacrylate) Containing Physical and Chemical Crosslinks. Journal of Applied Polymer Science. 89: 779-786.

[3] Boateng, J. S., Matthews, K. H., Stevens, H. N. E., and Eccleston, G. M. 2008. Wound Healing Dressings and Drug Delivery Systems: A Review. Journal of Pharmaceutical Sciences. 97(8): 2892-2923.

https://doi.org/10.1002/jps.

[4] Chen, H., Zhang, E., and Yang, K. 2014. Microstructure, Corrosion Properties and Bio-compatibility of Calcium Zinc Phosphate Coating on Pure Iron for Biomedical Application. Materials Science and Engineering C. 34(1): 201-206

https://doi.org/10.1016/j.msec.2013.09.010.

[5] de Carvalho, R. N. L., Torres Lourenço, N. M., Gomes, P. M. V., and da Fonseca, L. J. P. 2013. Swelling Behavior of
Gelatin-Ionic Liquid Functional Polymers. Journal of Polymer Science Part B: Polymer Physics. 51 (10): 817-825. https://doi.org/10.1002/polb.23252.

[6] Finch, C. A. 1983. Some Properties of Polyvinyl Alcohol and Their Possible Application. In C. A. Finch (Ed.). Chemistry and Technology of Water-Soluble Polymers. Springer Science Business Media New York. 287-288.

[7] Frykberg, R. G., and Banks, J. 2015. Challenges in the Treatment of Chronic Wounds. Advances in Wound Care. 4(9): 560-582.

https://doi.org/10.1089/wound.2015.0635.

[8] Ghosh, P. K., and Gaba, A. 2013. Phyto-extracts in Wound Healing. Journal of Pharmacy and Pharmaceutical Sciences. 16(5): 760-820.

https://doi.org/10.18433/J3831V.

[9] Govindarajan, M., Jebanesan, A., Reetha, D., Amsath, R., Pushpanathan, T., and Samidurai, K. 2008. Antibacterial Activity of Acalypha indica L. European Review for Medical and Pharmacological Sciences. 12: 299-302.

[10] Hess, C. T. 2008. Checklist for Factors Affecting Wound Healing. Advances in Skin and Wound Care. 24(4): 192.

[11] Rajaselvam, J., Benila mily, J. M., and Meena, R. 2012. A Study of Antimicrobial Activity of Acalypha Indica against Selected Microbial Species. International Journal of Pharma Sciences and Research. 3(9): 473-476.

[12] Saranraj, P., Stella, D., Sathiyaseelan, K., and Samuel, S. 2010. Antibacterial Potentiality of Ethanol and Ethyl Acetate Extract of Acalypha indica against Human Pathogenic Bacteria. Journal of Ecobiotechnology. 2(7): 23-27.

[13] Zahidin, N. S., Saidin, S., Mohamed Zulkifli, R., Muhamad, I. I., Ya'akob, H., and Nur, H. 2017. A Review of Acalypha indica L. (Euphorbiaceae) as Traditional Medicinal Plant and its Therapeutic Potential. Journal of Ethnopharmacology. 207: 146-173.

[14] Hruljova, J. 2014. Role of Specifically Interacting Solvents in Solvent Swelling of Kukersite Oil Shale Kerogen. Tallinn University of Technology.

[15] Islam, M. T., Dafader, N., Poddar, P., Khan, N. M. S., and Chowdhury, S. 2016. Studies on Swelling and Absorption Properties of the $Y^{-}$Irradiated Polyvinyl Alcohol (PVA)/Kappa-Carrageenan Blend Hydrogels. Journal of Advanced Chemical Engineering. 6(2): 6 . https://doi.org/10.4172/2090-4568.1000.

[16] Järbrink, K., Ni, G., Sönnergren, H., Schmidtchen, A., Pang, C., Bajpai, R., and Car, J. 2016. Prevalence and Incidence of Chronic Wounds and Related Complications: A Protocol for a Systematic Review. Systematic Reviews. 5(152): 1-6.

[17] Kannathasan, K., Senthilkumar, A., and Venkatesalu, V. 2011. In Vitro Antibacterial Potential of Some Vitex Species Against Human Pathogenic Bacteria. Asian Pacific Journal of Tropical Medicine. 4(8): 645-648. https://doi.org/10.1016/S1995-7645(11)60164-8.

[18] Ki, V., and Rotstein, C. 2008. Bacterial Skin and Soft Tissue Infections in Adults: A Review of Their Epidemiology Pathogenesis, Diagnosis, Treatment and Site of Care. Can. J. Infect. Dis. Med. Microbiol. 19(2): 174-184.

[19] Renewable Fuels Association. 2014. Chemical and Physical Characteristics of Ethanol and Hydrocarbon Fuels. Module 2. 1-17.

[20] S. K. Saxena. 2004. Polyvinyl Alcohol (PVA) (Vol. 1).

[21] Saha, A. K., Rahman, R., Shahriar, M., Saha, S. K., and Azad, N. Al. 2013. Screening of Six Ayurvedic Medicinal Plant Extracts for Antioxidant and Cytotoxic Activity. Journal of Pharmacognosy and Phytochemistry. 2(2): 181188.

[22] Singh, S., Alistair, Y., and McNaught, C. E. 2017. The Physiology of Wound Healing. Surgery-Oxford International Edition. 35(9): 473-477.

[23] Somchit, M. N., Rashid, R. A., Abdullah, A., Zuraini, A., Zakaria, Z. A., Sulaiman, M. R., Mutalib, A. R. 2010. In vitro Antimicrobial Activity of Leaves of Acalypha indica Linn. 
(Euphorbiaceae). African Journal of Microbiology Research. 4(20): 2133-2136.

[24] Thakur, R., Jain, N., Pathak, R., and Sandhu, S. S. 2011. Practices in Wound Healing Studies of Plants. EvidenceBased Complementary and Alternative Medicine. 17. https://doi.org/10.1155/2011/438056.
[25] Velnar, T., Bailey, T., and Smrkolj, V. 2009. The Wound Healing Process: An Overview of the Cellular and Molecular Mechanisms. The Journal of International Medical Research. 37(5): 1528-1542. 